\title{
24. Documenting the Inevitable: Voting behaviour at the 2013 Australian election
}

\author{
Clive Bean and Ian McAllister
}

In late June 2010, with the federal election looming, Kevin Rudd was replaced by his deputy, Julia Gillard, in a now infamous move against the serving prime minister (Simms and Wanna 2012). The election was held less than two months afterwards. Almost exactly three years later, in an ironic reversal of fortunes, the Australian Labor Party caucus reversed its stance and replaced Gillard with Rudd. As in 2010, the 2013 election also followed just over two months later.

The latter move, in particular, was a culmination of the disunity that had been evident within the Labor Government for most of its term of office. For a time the switch back to Rudd gave some hope that the Government's fortunes might be revived sufficiently to win the election, but the more realistic prospect was that Rudd's reintroduction as leader would reduce the size of the defeat that the Government would inevitably suffer.

The 2013 election was also held amid a backdrop of trenchant policy debates and criticism of the Government over its handling of issues such as the carbon tax, the ongoing arrival of boats carrying asylum seekers, the national school curriculum, the cost of health care, the introduction of the National Disability Insurance Scheme, government expenditure and the balancing of the federal budget, and the Government's general ability to manage the economy in an ongoing context of fiscally challenging times.

This chapter uses data from the 2013 Australian Election Study (AES), conducted by Clive Bean, Ian McAllister, Juliet Pietsch and Rachel Gibson (Bean et al. 2014) to investigate political attitudes and voting behaviour in the election. The study was funded by the Australian Research Council and involved a national survey of political attitudes and behaviour using a self-completion questionnaire mailed to respondents on the day before the 7 September election. The sample was a systematic random sample of enrolled voters throughout Australia, drawn by the Australian Electoral Commission. Respondents were given the option of returning the completed questionnaire by reply-paid mail or completing the survey online. Non-respondents were sent several follow-up mailings and the final sample size was 3,955, representing a response rate of 34 per cent. The data were weighted to reflect population parameters for gender, age, state and vote. 


\section{Voter engagement with the election}

The three years of government prior to the 2013 election was both tense and intense as the political fortunes of a rare minority government at the federal level in Australia waxed and waned. Seldom did the Government appear far from collapse and the status of its leader, Gillard, was under continual threat. It would have been difficult to say whether the political machinations of the parliamentary term would have turned the electorate off politics, to the extent that the 2013 election aroused little attention, or whether interest would have been piqued, as voters rallied to see how the election would resolve the political situation.

Table 1, which shows a set of voter orientations towards the election campaign and compares the current election with the preceding three, suggests the patterns of voter attention to the election were broadly similar in 2013 to other elections of the recent past, albeit towards the lower end of the interest range with, for example, 33 per cent of AES respondents taking a good deal of interest in the election campaign and 68 per cent caring a good deal which party won. Television remained the main medium through which voters followed the campaign, after which came newspapers, radio and the internet. Although the order of attention to these different media types remained the same as previously, the degree of attention to the two leading media dipped in 2013 compared to the two previous elections. On the other hand, the internet, while remaining the fourth and least popular source through which attention was paid to the campaign, continued to grow as a political news medium. Over 40 per cent now report using the internet for election news or information, 10 times the proportion of voters who reported doing so when this question was first asked after the 1998 election (Bean and McAllister 2000: 176). An examination of the figures from 2007, 2010 and 2013, however, shows that the rate of growth in the uptake of the internet for campaign news has slowed.

Table 1: Voter attitudes towards the election campaign 2004-13 (percentages)

\begin{tabular}{|l|r|r|r|r|}
\hline & $\mathbf{2 0 0 4}$ & $\mathbf{2 0 0 7}$ & $\mathbf{2 0 1 0}$ & $\mathbf{2 0 1 3}$ \\
\hline Took 'a good deal' of interest in the election campaign overall & 30 & 40 & 34 & 33 \\
\hline Cared 'a good deal' which party won & 72 & 76 & 68 & 68 \\
\hline Paid 'a good deal' or 'some' attention to the campaign: & & & & \\
$-\quad$ in newspapers & 57 & 61 & 62 & 50 \\
- on television & 69 & 77 & 77 & 70 \\
- on radio & 44 & 50 & 48 & 45 \\
$\quad$ on the internet & - & 16 & 29 & 34 \\
\hline Used the internet for election news or information & 12 & 20 & 36 & 41 \\
\hline Watched the televised leaders' debate & 35 & 46 & 47 & 32 \\
\hline Thought Howard (2004, 2007)/Gillard (2010)/Rudd & 25 & 13 & 37 & 30 \\
performed better in the debate & & & & \\
\hline
\end{tabular}

Sources: Australian Election Studies $2004(\mathrm{n}=1,769), 2007(\mathrm{n}=1,873), 2010(\mathrm{n}=2,061)$ and $2013(\mathrm{n}=3,955)$. 
The bottom section of Table 1 shows that just under a third of the electorate reported watching the televised leaders' debate held on 11 August (a significantly lower proportion than for the equivalent event before the previous two elections). Respondents saw the debate as being roughly even, with 30 per cent saying they thought that Rudd performed better than the Opposition Leader, Tony Abbott, 31 per cent saying they thought Abbott performed better and 39 per cent saying the two leaders did about equally.

Table 2 contains several indicators which address the question of the relative stability versus volatility of electoral behaviour in Australia. In many countries, an increase in the number of voters not deciding how to vote until during the election campaign has been apparent (McAllister 2002), although in Australia the proportion has tended to vary with the nature of the election, so that, for example, most people had made up their minds before the campaign in 2007, while in 2010 nearly half the electorate was still to decide when the campaign began. The figure for 2013 of 41 per cent saying they did not definitely decide how to vote until during the election campaign is in the middle of the range. Some 30 per cent said they seriously thought of voting for a party other than that which they did eventually vote for, while 46 per cent said that they have always voted for the same party.

Table 2: Measures of electoral stability and partisanship 2004-13 (percentages)

\begin{tabular}{|l|r|r|r|r|}
\hline & \multicolumn{1}{|c|}{2004} & \multicolumn{1}{|c|}{2007} & \multicolumn{1}{l|}{2010} & \multicolumn{1}{l|}{2013} \\
\hline Decided definitely how to vote during campaign period & 39 & 29 & 47 & 41 \\
\hline $\begin{array}{l}\text { Seriously thought of giving first preference to another } \\
\text { party in the House of Representatives during election } \\
\text { campaign }\end{array}$ & 25 & 23 & 29 & 30 \\
\hline Always voted for same party & 50 & 45 & 52 & 46 \\
\hline Identifier with one of the major parties & 77 & 77 & 78 & 73 \\
\hline Not a party identifier & 16 & 16 & 14 & 17 \\
\hline Very strong party identifier & 21 & 25 & 19 & 21 \\
\hline
\end{tabular}

Sources: Australian Election Studies $2004(\mathrm{n}=1,769), 2007(\mathrm{n}=1,873), 2010(\mathrm{n}=2,061)$ and $2013(\mathrm{n}=3,955)$.

One of the key indicators of stability in modern democracies is party identification, the tendency of voters to support one or other of the major political parties consistently over a long period of time, a phenomenon that has been particularly strong and persistent in Australia (Aitkin 1982; McAllister 2011), while in many other countries it has declined (Dalton and Wattenberg 2000; Webb, Farrell and Holliday 2003; Dalton 2008). After some signs of decline in the second half of the 1990s (Bean and McAllister 2000: 183), the level of party identification again steadied throughout the first decade of the 21st century, with the proportion of voters identifying with one of the major parties consistently hovering at just under 80 per cent (Bean and McAllister 2012: 343). In 2013, there is the first sign for seven elections that party identification may be declining further in Australia. Only 73 per cent-less than three-quarters- 
of AES respondents reported an identification with one of the major political parties in 2013, a drop of 5 per cent from 2010. Minor parties soak up some of the remainder, but the proportion not identifying with any party at all has increased to 17 per cent, still low by world standards, but higher than ever before in Australia. Among those who are party identifiers, the percentage that supports their party strongly persists at around 20 per cent.

\section{Social structure and electoral choice}

There is little doubt that patterns of partisan attachment relating to sociodemographic groupings have changed and weakened over time in Australia (McAllister 2011). Yet, there remains some variability from election to election and examination of these relationships can aid understanding of the ebb and flow of the political fortunes of the major parties. Accordingly, Tables 3 and 4 set out the patterns of support for the parties in 2013 by various measures of social structure. Table 3 begins with gender. A clear reversal of the traditional gender gap had been evident in 2010 (Bean and McAllister 2012: 344). In 2013 we appear to have returned to the more common pattern of recent years in which there has been little or no gender gap (Bean and McAllister 2009; McAllister 2011: 115). The only sense of gender being a factor in party support in this election relates to the Greens, which drew more support from women than men.

Table 3: Vote by gender, age, region and religion in 2013 (percentages)

\begin{tabular}{|l|r|r|r|r|r|}
\hline & Labor & Liberal-National & Greens & Other & (N) \\
\hline Gender & 34 & & & & \\
Male & 33 & 46 & 7 & 13 & $(1,735)$ \\
Female & & 45 & 10 & 12 & $(1,862)$ \\
\hline Age group & 36 & 35 & 12 & 17 & $(362)$ \\
Under 25 & 34 & 42 & 12 & 11 & $(1,167)$ \\
25 to 44 & 35 & 45 & 8 & 12 & $(1,266)$ \\
45 to 64 & 29 & 56 & 3 & 11 & $(777)$ \\
65 and over & & & & & \\
\hline Region & 30 & 47 & 7 & 16 & $(987)$ \\
Rural & 35 & 45 & 10 & 11 & $(2,570)$ \\
Urban & & & & & \\
\hline Religious denomination & 35 & 52 & 4 & 9 & $(829)$ \\
Catholic & 28 & 56 & 3 & 13 & $(655)$ \\
Anglican & 27 & 55 & 5 & 14 & $(369)$ \\
Uniting & 34 & 46 & 6 & 15 & $(567)$ \\
Other & 39 & 33 & 18 & 12 & $(1,153)$ \\
No religion & & & & & \\
\hline Church attendance & 54 & 4 & 14 & $(580)$ \\
At least once a month & 27 & 54 & 7 & 9 & $(704)$ \\
At least once a year & 30 & 48 & 8 & 12 & $(555)$ \\
Less than once a year & 32 & 38 & 11 & 13 & $(1,731)$ \\
Never & 38 & & &
\end{tabular}


Younger voters disproportionately supported minor parties in 2013. This was true not only for the Greens, but also for the substantial group of 'other' minor party supporters, a category capturing a diverse range of votes but in which the largest group is the Palmer United Party. Older voters opted very strongly for the Coalition Liberal and National parties, as they had done in 2010 (Bean and McAllister 2012). The patterns of urban versus rural support for the minor parties was arguably also a more interesting feature in 2013 than the persistent, if modest, urban-rural divide in support for the major parties. Rural voters supported the other minor parties more strongly but the Greens less strongly than urban voters.

For the second election in a row, more Catholic voters supported the Coalition than Labor, this time by a substantial margin. Although Labor is still favoured by Catholics more than Protestants, it derives more electoral support from those with no religion than from any religious denomination. Much more starkly, this situation is also true for the Greens. The bastion of religious support for the Coalition continues to be Protestant members of the electorate and also those who attend church more frequently, whereas support for both Labor and the Greens rises as church attendance declines. The dominance of the Coalition in this election, however, is reflected in the fact that the Coalition attracted the support of as many voters who never attend church as Labor.

Table 4: Vote by socio-economic indicators in 2013 (percentages)

\begin{tabular}{|l|r|r|r|r|r|}
\hline & Labor & Liberal-National & Greens & Other & (N) \\
\hline Education & & & & & \\
No post-school qualifications & 34 & 48 & 6 & 12 & $(1,012)$ \\
Non-degree qualifications & 33 & 48 & 6 & 14 & $(1,380)$ \\
University degree & 35 & 39 & 16 & 11 & $(1,139)$ \\
\hline Occupation & & & & & \\
Manual & 38 & 41 & 7 & 14 & $(948)$ \\
Non-manual & 32 & 48 & 10 & 10 & $(2,192)$ \\
\hline Employment & 23 & & & & \\
Self-employed & 39 & 57 & 8 & 12 & $(564)$ \\
Government employee & & 38 & 12 & 11 & $(820)$ \\
\hline Trade Union Membership & 46 & & & & \\
Union member & 30 & 51 & 12 & 12 & $(695)$ \\
Not a union member & & 50 & 8 & 12 & $(2,670)$ \\
\hline
\end{tabular}

Source: Australian Election Study $2013(n=3,955)$.

Table 4 contains the equivalent figures for the socio-economic variables of education, occupation, employment and union membership. Education is significant for the strong support for the Greens of those with tertiary degrees and for the relatively low support for the Coalition among the same group. The figures for occupation and vote allow us to calculate the index of class voting 
(the manual vote for Labor minus the non-manual vote for Labor). Class voting has become much weaker in Australia than in years gone by and it has been quite variable in recent elections. In 2013 it registered at 6 per cent, which is a reduction from the previous election, but not as low as it has gone on occasions in the past two decades (McAllister 2011: 152). Other minor parties appear to have eaten into Labor support among blue-collar voters, with 14 per cent of manual voters opting for such parties as opposed to 10 per cent of non-manual voters. Again, the Greens profile is the reverse, in that they attracted more support from non-manual than manual voters.

Further down, Table 4 shows that clear patterns of differential party support continue to be evident based on employment status or sector. The self-employed are much more likely to vote Liberal-National, while those employed in the public sector are more likely to support Labor and also the Greens. The data in the last section of the table contain some concerning messages for the Labor Party. While a clear divide continues to be apparent in the political leanings of union members compared to non-union members, Labor on this evidence no longer receives the vote of a majority of unionists. The Greens, in particular, have eaten into this support base, so that only 46 per cent of union members gave their first preference vote to the Labor Party in the 2013 federal election.

\section{The party leaders}

Analysis of the 2010 election had concluded that, while no party leader was particularly popular, Abbott's lack of rapport with voters and greater unpopularity made a substantial contribution to the Coalition's narrow loss of a closely fought contest. With the Labor Government in such disarray over its leadership and the time Abbott had to establish himself as a credible leadership figure over the three years since, it was possible that in 2013 the tables might be turned. There is some evidence in the section that follows that this may indeed have been the case.

Table 5: Leader and party evaluations in 2013 (means on 0-10 scale)

\begin{tabular}{|l|r|r|r|r|r|}
\hline Leader & Mean & \multicolumn{1}{l|}{ Standard deviation } & Party & Mean & \multicolumn{1}{l|}{ Standard deviation } \\
\hline Kevin Rudd & 4.1 & 3.2 & Labor & 4.8 & 3.0 \\
\hline Tony Abbott & 4.3 & 3.4 & Liberal & 5.0 & 3.4 \\
\hline Warren Truss & 4.3 & 2.2 & National & 4.5 & 2.7 \\
\hline Christine Milne & 3.8 & 2.5 & Greens & 3.8 & 3.0 \\
\hline Julia Gillard & 4.0 & 3.1 & & & \\
\hline
\end{tabular}

Source: Australian Election Study 2013 (n=3,955). 
As Table 5 demonstrates, none of the leaders was seen in a positive light by the respondents in the 2013 AES. Even compared to 2010 (Bean and McAllister 2012: 347), the leadership ratings were generally low. Abbott himself, however, with a mean rating of 4.3, scored no worse than he had done three years previously. By contrast, the mean scores for both of the key protagonists on the Labor side - the newly restored Rudd and the recently deposed Gillard-had fallen substantially. The result was that Abbott was now narrowly ahead of his principal opponent in terms of his leadership rating. Rudd's evaluation stood at 4.1 , on a scale in which zero represents a strong dislike, five represents a neutral position and 10 represents a strong liking for the leader. Both leaders, however, lagged well behind the equivalent ratings of their parties, although again, neither of the major parties could be called popular with the electorate, the highest party score being 5.0 for the Liberal Party. The Greens' reversal of fortunes in this election is reflected in the low scores for both the Party and its leader, Christine Milne.

Table 6 further explores the composition of voter evaluations of Abbott and Rudd. In 2010, Abbott had trailed Gillard on every one of the nine leadership characteristics listed in Table 6 (Bean and McAllister 2012: 348). In 2013, he headed Rudd in five of the nine. Abbott was seen as more competent, more sensible, as providing stronger leadership, as more honest and more trustworthy than Rudd. One qualification is that on several of these qualities, notably honesty and trustworthiness, while ahead of Rudd, Abbott himself did not score highly and indeed there is no one quality for which a very large proportion of respondents did say it described him extremely or quite well. Rudd stands out as having been rated highly for his intelligence and knowledge, while few saw him as trustworthy.

Table 6: Perceived leadership qualities of Kevin Rudd and Tony Abbott in 2013 (percentage saying quality describes leader extremely well or quite well)

\begin{tabular}{|l|r|r|}
\hline Quality & Kevin Rudd & Tony Abbott \\
\hline Intelligent & 84 & 68 \\
\hline Compassionate & 48 & 46 \\
\hline Competent & 51 & 57 \\
\hline Sensible & 49 & 52 \\
\hline Provides strong leadership & 40 & 60 \\
\hline Honest & 38 & 45 \\
\hline Knowledgeable & 80 & 58 \\
\hline Inspiring & 33 & 31 \\
\hline Trustworthy & 29 & 40 \\
\hline
\end{tabular}

Source: Australian Election Study 2013 (n=3,955). 


\section{Issues in the 2013 election}

As described in the introduction to the chapter, there was no shortage of (often controversial) policy issues on the agenda in the lead up to the 2013 election, including the carbon tax, refugees and asylum seekers, education, health care and management of the economy. A growing body of research has also been documenting how voters have their own issue agendas, which may or may not coincide with the emphasis placed on these issues by the political parties during the election campaign (Goot and Watson 2007; Bean and McAllister 2012; McAllister, Bean and Pietsch 2012). Thus, health, education, economic management and taxation repeatedly feature as election issues of significance. So it was in 2013.

Table 7 shows that health and Medicare, and management of the economy scored equally as the issues rated by the most voters as being extremely important (68 per cent). These were followed by education (with 63 per cent rating it an extremely important issue), but then there was a considerable gap, with no other issue rated as extremely important by a majority of the AES sample. Refugees and asylum seekers, immigration and the environment rated in the mid-40s, followed by taxation, the carbon tax and global warming, in the mid-30s, and finally industrial relations, with only 29 per cent rating it as an issue of extreme importance.

Table 7: Importance rating of election issues (percentage describing issue as extremely important) and party differential (percentage saying Labor closer on issue minus percentage saying Liberal-National closer) in 2013

\begin{tabular}{|l|l|l|l|l|l|l|}
\hline \multicolumn{9}{|c|}{ Importance } \\
\hline & $\begin{array}{l}\text { All } \\
\text { voters }\end{array}$ & $\begin{array}{l}\text { Labor } \\
\text { voters }\end{array}$ & $\begin{array}{l}\text { Liberal-National } \\
\text { voters }\end{array}$ & $\begin{array}{l}\text { Green } \\
\text { voters }\end{array}$ & $\begin{array}{l}\text { Other } \\
\text { voters }\end{array}$ & $\begin{array}{l}\text { Party } \\
\text { differential }\end{array}$ \\
\hline Taxation & 37 & 32 & 43 & 16 & 35 & -9 \\
\hline Immigration & 43 & 36 & 51 & 36 & 35 & -16 \\
\hline Education & 63 & 73 & 56 & 70 & 61 & +17 \\
\hline The environment & 43 & 53 & 27 & 82 & 44 & +13 \\
\hline Industrial relations & 29 & 34 & 26 & 20 & 28 & +0 \\
\hline Health and Medicare & 68 & 75 & 65 & 65 & 63 & +10 \\
\hline $\begin{array}{l}\text { Refugees and asylum } \\
\text { seekers }\end{array}$ & 46 & 41 & 50 & 51 & 40 & -22 \\
\hline Global warming & 33 & 46 & 16 & 72 & 34 & +12 \\
\hline The carbon tax & 36 & 32 & 37 & 45 & 34 & -9 \\
\hline $\begin{array}{l}\text { Management of the } \\
\text { economy }\end{array}$ & 68 & 6 & 81 & 37 & 63 & -21 \\
\hline
\end{tabular}

Source: Australian Election Study 2013 (n=3,955). 
The breakdown of issue importance by party shows that, for the two leading issues, health mattered more to Labor voters and management of the economy to Coalition voters. Labor voters were also particularly concerned about education, while both taxation and the issue of refugees and asylum seekers were more important to Coalition voters. The most distinctive issue profile was for Greens supporters, who predictably rated the environment and global warming as far more important than any other party group (with 82 per cent of Greens voters saying they thought the environment was an extremely important issue and 72 per cent similarly rating global warming) and management of the economy as far less important (only 37 per cent said it was extremely important). The level of concern about global warming among Greens voters has risen considerably since 2010 (Bean and McAllister 2012: 349). Both Greens and Coalition voters gave the issue of refugees and asylum seekers an elevated level of importance, but almost certainly with quite different policy outcomes in mind. Voters for 'other' parties largely mirrored the electorate as a whole, displaying more or less equal concern about health, the economy and education.

At the far right of Table 7, the column headed 'party differential' shows in summary which of the two major parties appears to have had an advantage on each issue in terms of the proportion of voters saying the party's policies came closer to their own views. When there is a plus sign the advantage lay with Labor; a negative sign means the balance was in favour of the LiberalNational parties. For one issue (industrial relations) there was no advantage to either party. Of the remainder, the Coalition had an advantage on five and Labor on four. Of the two highest rating issues, the Coalition had the advantage on economic management while Labor had the advantage on health and Medicare. The Coalition's lead was greater on the economy than Labor's on health, but in addition Labor had the advantage on the next highest rated issue, education. Interestingly, the Coalition also had a large advantage on the hotly debated issue of refugees and asylum seekers.

\section{Conclusion: Weighing all the factors together}

While the raw issue data provide pointers to which issues may have mattered in the election, what they cannot do on their own is reveal which issues and other variables actually influenced people's votes, independent of all other considerations. What is required to achieve this is a multivariate analysis to assess the net impact of all the relevant factors and this is the task of the final section of the chapter. This will allow us to conclude, for example, which of the issues really did make a difference to the election outcome. The multivariate procedure isolates the separate influence on the vote of the variables examined earlier in the chapter, including the socio-demographic measures, party identification, the 
summary leadership ratings and the 10 campaign issues discussed in the section above. The results are shown in Table 8. Only those variables with statistically significant effects appear in the table. Methodological details are outlined in the appendix.

Of all the factors examined, nine feature in the table. Of these, only one is a socio-demographic variable (gender). Five of the 10 issue variables had significant effects on the vote, as did the two-party leader evaluations and party identification. The effect for gender, though statistically significant, is small, indicating that when other factors are controlled, men were around 3 per cent less likely to vote for the Liberal-National Coalition, as opposed to Labor, than women. What is interesting about this result is that it reverses the direction of the effect found in the equivalent study of the last election, in which men were, by the same percentage, more likely than women to vote for the Coalition (Bean and McAllister 2012). The 2013 pattern returns us to the more common direction of association between gender and partisan support, while also reinforcing the small size of the gender gap in contemporary Australian politics. In addition, the finding gives further weight to the view that the atypical relationship between gender and the vote found in 2010 related to the presence of Australia's first female prime minister (Tranter 2011; Denemark, Ward and Bean 2012).

Table 8: Significant influences on voting behaviour in 2013 (multiple regression)

\begin{tabular}{|l|r|r|r|}
\hline & $\begin{array}{l}\text { Unstandardised } \\
\text { regression coefficient }\end{array}$ & \multicolumn{2}{|l|}{$\begin{array}{l}\text { Standardised regression } \\
\text { coefficient }\end{array}$} \\
\hline Gender (male) & -0.03 & -0.03 \\
\hline Party identification & 0.42 & 0.41 \\
\hline Kevin Rudd & -0.17 & -0.12 \\
\hline Tony Abbott & 0.23 & 0.17 \\
\hline Taxation & 0.06 & 0.04 \\
\hline Education & 0.07 & 0.05 \\
\hline Health and Medicare & 0.09 & & 0.08 \\
\hline Refugees and asylum seekers & 0.07 & & 0.05 \\
\hline Management of the economy & 0.09 & & 0.08 \\
\hline R-squared & & 0.69 & \\
\hline
\end{tabular}

Note: Entries in the table are statistically significant at $\mathrm{p}<.05$ or better. Further methodological details can be found in the appendix.

Source: Australian Election Study $2013(n=3,955)$.

Party identification routinely has the largest electoral impact by far and this election was no exception. However, consistent with the evidence of decline 
in the level of partisanship noted earlier in the chapter, there was a noticeable reduction in the size of the party identification effect compared to previous elections (Bean and McAllister 2009 and 2012).

By contrast, leadership effects, while much smaller than the party influence, remained at similar levels to the last election and again reinforced their persistence over time in Australian elections (Senior and van Onselen 2008). For example, the unstandardised regression coefficient for Abbott shows that voters who strongly liked the Opposition Leader were some 23 per cent more likely to vote for the Coalition parties than for Labor compared to those who strongly disliked him. Voters who strongly liked Rudd were around 17 per cent more likely to vote Labor than those who strongly disliked the Prime Minister.

All of the five significant issue variables had similarly modest effects, led by the two that had registered as being of most concern to voters - management of the economy and health and Medicare - but also featuring two that, although topical, had in the initial assessment of issues above seemed less obviously important to voters - refugees and asylum seekers and taxation-as well as education. Four of these five issues, economic concerns, tax, health and more latterly education, repeatedly stamp themselves as important in the electoral decision-making of the Australian electorate (Bean and McAllister 2009 and 2012).

While the size of the issue effects, in particular, and also the leader effects is small, these factors nonetheless potentially have a significant role to play in explaining the election outcome, depending on the extent to which the electorate favoured one side over the other. We have seen, for instance, from Table 7 that the balance of opinion on the issues of refugees and asylum seekers, management of the economy and taxation all favoured the Coalition, while the balance favoured Labor on the issues of education and health. We also saw that voter evaluations of both leaders were relatively low. It is possible to calculate the effect of each variable on the net balance of the party vote at the election by combining the size of the effect on individual voters (the regression coefficient) with the size and direction of the balance of voter opinion (derived from the mean of the variable). Details of the method of these calculations are given in the appendix.

As it turns out, the negative appraisals of the two major party leaders more or less cancelled each other out. The calculations show that Abbott effectively cost the Coalition just over 1.5 per cent of the vote, while Rudd cost the Labor Party a similar percentage and thus the two effects largely neutralised each other. With respect to issues, the largest impact on the party balance came from management of the economy which, when the combination of its effect and the balance of opinion is taken into account, conferred a net advantage of 1 per cent of the vote to the Coalition. The net effects of refugees and asylum seekers 
and taxation together added almost another 1 per cent to the Coalition's vote, but this was counteracted by the combined effects of health and education, which delivered just over 1 per cent to Labor. Overall, these issue effects left the Liberal-National parties a little under 1 per cent of the vote better off than they would have been if none of these factors had been in play. These calculations thus give some insight into the policy issues that drove voter behaviour in an election at which defeat for the Government was virtually inevitable.

\section{Appendix}

The equation in Table 8 was estimated by ordinary least squares regression analysis with pairwise deletion of missing data. The dependent variable, first preference vote for the House of Representatives in the 2013 federal election, was scored zero for Labor, 0.5 for minor parties and one for Liberal-National. Party identification was likewise scored zero for Labor, 0.5 for minor parties or no party identification and one for Liberal-National. Apart from age, scored in years, all other independent variables were either 0-1 dummy variables or scaled to run from a low score of zero to a high score of one.

The issue variables were computed by combining the importance ratings with the party closer to the respondent, so that at one end those who rated the issue as extremely important and felt closer to the Labor Party on the issue were scored zero and at the other end of the scale those who rated the issue as extremely important and felt closer to the Coalition on the issue were scored one.

For both the issue and leader variables, the calculations showing the impact of these factors on the party balance were made by multiplying the unstandardised regression coefficient by the amount by which the mean of the variable deviated from the neutral point of 0.5. For management of the economy the deviation was +0.11 , for refugees and asylum seekers it was +0.09 , for taxation it was +0.05 , for health and Medicare it was -0.05 and for education it was -0.09 . In the case of the leadership variables, the deviation for Rudd was -0.09 and for Abbott it was -0.07 .

\section{References}

Aitkin, Don. 1982. Stability and Change in Australian Politics. 2nd edn. Canberra: Australian National University Press. 
Bean, Clive and McAllister, Ian. 2000. 'Voting Behaviour'. In Marian Simms and John Warhurst (eds), Howard's Agenda: The 1998 Australian Election, St Lucia: University of Queensland Press.

Bean, Clive and McAllister, Ian. 2009. 'The Australian Election Survey: The Tale of the Rabbit-less Hat. Voting Behaviour in 2007'. Australian Cultural History 27: 205-18.

Bean, Clive and McAllister, Ian. 2012. 'Electoral Behaviour in the 2010 Australian Federal Election'. In Marian Simms and John Wanna (eds), Julia 2010: The caretaker election, Canberra: ANU E-Press.

Bean, Clive, McAllister, Ian, Pietsch, Juliet and Gibson, Rachel. 2014. Australian Election Study, 2013: Codebook. Canberra: Australian Data Archive, The Australian National University.

Dalton, Russell J. 2008. Citizen Politics: Public Opinion and Political Parties in Advanced Industrial Democracies. 5th edn. Washington, DC: CQ Press.

Dalton, Russell J. and Wattenberg, Martin P (eds). 2000. Parties without Partisans: Political Change in Advanced Industrial Democracies. Oxford: Oxford University Press.

Denemark, David, Ward, Ian and Bean, Clive. 2012. 'Gender and Leader Effects in the 2010 Australian Election'. Australian Journal of Political Science 47: 563-78.

Goot, Murray and Watson, Ian. 2007. 'Explaining Howard's Success: Social Structure, Issue Agendas and Party Support, 1993-2004'. Australian Journal of Political Science 42: 253-76.

McAllister, Ian. 2002. 'Calculating or Capricious? The New Politics of Late Deciding Voters'. In D M Farrell and R Schmitt-Beck (eds), Do Political Campaigns Matter? Campaign Effects in Elections and Referendums, London and New York: Routledge.

McAllister, Ian. 2011. The Australian Voter: Fifty Years of Change. Sydney: UNSW Press.

McAllister, Ian, Bean, Clive and Pietsch, Juliet. 2012. 'Leadership Change, Policy Issues and Voter Defection in the 2010 Australian Election'. Australian Journal of Political Science 47: 189-209.

Senior, Philip and van Onselen, Peter. 2008. 'Re-examining Leader Effects: Have Leader Effects Grown in Australian Federal Elections 1990-2004?' Australian Journal of Political Science 43: 225-42. 
Abbott's Gambit: The 2013 Australian Federal Election

Simms, Marian and Wanna, John (eds). 2012. Julia 2010: the caretaker election. Canberra: ANU E-Press.

Tranter, Bruce. 2011. 'Gendered Voting at the 2010 Australian Election'. Australian Journal of Political Science 46: 707-17.

Webb, Paul, Farrell, David and Holliday, Ian (eds). 2003. Political Parties at the Millennium: Adaptation and Decline in Democratic Societies. Oxford: Oxford University Press. 
This text taken from Abbott's Gambit: The 2013 Australian Federal Election, edited by Carol Johnson and John Wanna, published 2015 by ANU Press, The Australian National University, Canberra, Australia. 